\title{
Teacher's Knowledge about First Aid in the School Environment: Strategies to Develop Skills
}

\begin{abstract}
Kelle de Lima Rodrigues ${ }^{1}$, Jennifer Yohanna Ferreira de Lima Antão², Gleyciane Leandro Silveira Sobreira', Ruth Nobre de Brito ${ }^{1}$, Gislaine Loiola Saraiva Freitas ${ }^{1}$, Saranádia Caeira Serafim ${ }^{1}$, Hermes Melo Teixeira Batista ${ }^{2}$, Luis Fernando Barbosa Tavares ${ }^{2}$, Camila Macedo de Figueiredo ${ }^{1}$, Cícero Macedo $\mathrm{Cruz}^{2}$, Ankilma do Nascimento Andrade Feitosa ${ }^{3}$, Luiz Carlos de Abreu², Italla Maria Pinheiro Bezerra ${ }^{2,3}$
\end{abstract}

\section{Abstract}

Emergency situations occur anywhere and at any time, however, schools generate a significant concern because accidents happen routinely and teachers are the first ones to perform the assistance measures. Given this reality, a training course or even the inclusion of first aid knowledge in the curriculum of schools is made necessary. Based on what is exposed, this study aimed to understand the role of teachers facing urgency and emergency situations in the school context. Descriptive study with a qualitative approach developed in the city of Juazeiro do Norte, Ceara, Brazil, having as scenario a kindergarten, elementary and high school from a private network and eighteen active teachers from this institution as informants. The empirical material was collected from semi-structured interviews and analyzed following the steps of technical analysis of content proposed by Minayo (2010). It was evident that teachers have a perception that is very close to the first aid concepts; however, it is still very restricted to the concept of disease prevention and not the health promotion in the school context. The same study also revealed the importance of maintaining a calm behavior in front of an urgency and emergency situation; however, many teachers do not feel fully prepared to act when facing an accident. Teachers also highlighted the facilities and difficulties in carrying out these actions, emphasizing the access to materials that are required to realize the first aid, however, having these material is not enough, since the lack of knowledge still prevails as the greatest difficulty, revealing that having the materials is not sufficient and teachers need to know how to use them. It was clear that teachers act in
1 Faculdade de Juazeiro do Norte - FJN. Juazeiro do Norte, CE, Brazil.

2 Laboratório de Delineamento de Estudos e Escrita Científica. Departamento de Saúde da Coletividade. Faculdade de Medicina do $A B C$, Santo André, SP, Brazil.

3 Escola de Artes, Ciências e Humanidades da Universidade de São Paulo. São Paulo, Brazil.

\section{Contact information:}

Italla Maria Pinheiro Bezerra.

” itallamaria@hotmail.com 
urgency and emergency situations to ensure the student's lives; however, it is necessary to have the qualification for this role. The need to explore strategies in schools aimed to promote specific knowledge regarding first aid actions for the teachers is revealed. Thus, teachers will become more confident in the provision of care avoiding future consequences.

\section{Keywords}

First Aid; Teachers; Schools.

\section{Introduction}

Emergency situations occur anywhere and at any time, whether on the street, at home or even at a school environment, however, in the schools the care taken should be redoubled because students take advantage of the breaks between lessons to practice their mischief along with friends. These games when performed incorrectly can cause serious consequences, often irreversible, reaching to death if not helped properly [1].

Based on a study performed in a school in France, one can see that $52.8 \%$ of the accidents occur during physical activity and $12.7 \%$ during breaks. In relation to the injuries, obtained data were: bruises $50.7 \%$, $18.7 \%$ injuries, tendonitis $11.7 \%, 9.2 \%$ distension and others $7.3 \%$ [2].

Clinical conditions are highlighted, such as, allergic crises, which are gaining prominence in schools in recent years, mainly caused by food, drugs and insect bites. About $20 \%$ of children suffering from allergies have their first episode in the school environment [3].

It is known, that anyone can perform the first care to the victim at the scene, as long as this person has the basic knowledge about actions that should be taken. With regards to the school context, there are the teachers who are the professionals who are in direct contact with students.

However, due to the lack of knowledge from them, facing emergency situations, some problems may occur such as: mishandling of the victim, as well as the request of a rescue team without its necessity. The training of these professionals is therefore necessary, considering that when the procedures are performed quickly and efficiently the potential health risks to the victim are minimized [4].

In a study performed with teachers and school managers, it was found that the traditional training of teacher does not include specific actions of health care. This brings out the need for training of these professionals working directly in the schools with a view to increase their level of knowledge and improve the care provided to students [5].

To improve the quality of life in the school environment, an interaction between health/education for both teachers and for students is needed, because education is one of the main criteria for promotion and protection of health [6].

Faced with the above discussions, it is clear that although there is a high number of accidents in the school environment, the proposal of actions involving the health and education with relation to first aid actions is still a challenge and this implies with the current picture of unqualified teachers and unprepared to provide the initial care at the scene, often aggravating the victim's situation because of the execution of incorrect maneuvers.

Therefore, the research presents itself as relevant, given that possible harm to the victim could be avoided if teachers obtained the necessary knowledge to properly act when in front of the victim. Thus, the research may guide public policies that can put the theme of first aid in the school context in part- 
nership with health or even reviewing pedagogical political projects so this discipline can be included in the curriculum.

The objective of this study is to understand the role of teachers facing urgency and emergency situations in the school context.

\section{Methods}

Of descriptive nature held in Juazeiro do Norte, Ceara, Brazil. The scenario was a kindergarten, elementary and high school from private network located in the mentioned city. Eighteen teachers who work in the kindergarten of the school participated in this study, the inclusion criteria was: teachers working for more than six months in the institution.

Data collection was performed by applying a semi-structured interview which addressed awareness about first aid and its relationship with the school context.

The speech saturation process was still considered to reach the end of data collection. It is considered that the speech saturation process is based on when the researcher examines all the gathered information with a certain number of participants and notices that new interviews begin to exhibit repetitions of the subject, favoring negligible addition to the research in view of its objectives [7].

For the organization of the data, the technique of content analysis was used. According to Minayo [8] in the content analysis technique, the data were organized following proposed steps for better analysis of the data collected. These above steps are: pre-analysis, material exploration, treatment of obtained results and interpretation.

The study was submitted to the Ethics and Research Committee of the Faculdade de Juazeiro do Norte - FJN and forwarded to the Plataforma Brasil, receiving an approved feedback under protocol number 967780.

\section{Results and Discussion}

As already mentioned, the informants of the study were the teachers who work in a kindergarten at a private school, making a total of eighteen participants.

Starting from the methodologic orientation of analysis we identified themes that relate to notions of first aid; actions that must be performed when facing an accident; difficulties or facilities encountered in implementing these actions; the importance of providing a quality care to minimize possible risks to the victim.

These themes allowed the construction of the following categories: 1- Help to sustain life and prevent complications: perceptions about first aid; 2- Keep calm, ask for help: teacher's performance when facing a school accident; 3- We have the kit, but we do not have the knowledge: elements that facilitate or difficult the performance of teachers.

\section{"Help to sustain life and prevent} complications": perceptions about first aid First aid does not exceed 120 years and it has a history considered current. Since its beginning, first aid are intended to provide the first temporary care in a quickly way to a person who is injured or fell ill briefly, being paramount at the time of an occurrence for assisting in the identification of the actual condition in which the victim is [9].

Therefore, the importance for the teachers of a school environment to understand the concept of first aid is revealed, since they are inserted in an environment enabled to the event of numerous accidents. In this sense, when approaching to this reality, it became clear that the informants of the study perceive it sometimes as a way to prevent complications and other times as actions that should be taken to keep people's lives.

Procedure provided to an injured person to avoid the worst.

Teacher. 7. 
I believe it is the care provided to the victim in the accident and that care needs to be done fast to avoid compromising the victim.

Teacher. 9.

I believe they are preventive measures to avoid any harm to the victim.

Teacher. 10.

I think it is important and this is to avoid the worst, because usually accidents happen anywhere, but if we have a notion of what to do at the right time, we can even prevent a matter of death, right?

Teacher. 1.

It is the act we do to help someone in order to keep the person alive. Teacher.

Teacher. 17.

I think if all teachers had this basic understanding of first aid, certainly it would be easier to help in more serious situations and lives could often be saved.

Teacher. 4

Then, it is apprehended that this perception is closer to first aid concepts, however, it is still very restricted to the concept of disease prevention and not of health promotion in the school environment. This is an evidence that restricts teachers to act only when there is a disease and not as multipliers, in other words, as health educators in order to build knowledge together with the students about actions that promote their health, in a perspective to make them capable to act when facing emergency situations, as well as in the prevention of these problems.

Cases of accidents at school environment only increase, this happens due to the high number of students there is in this environment, as well as their participation in various physical activities, thus generating a huge concern for teachers and school management.
Teacher's knowledge about first aid is essential, since when an accident occurs teachers need to be able to act responsibly in order to preserve the victim's life [10].

There is still a significant lack of preparation of teachers at the time of an occurrence, the insecurity and nervousness may result in improper handling of the victim and can further aggravate the victim's situation. Thus, the implementation of training in the school context will contribute to the training of qualified teachers with emphasis on promotion and prevention of these accidents [11].

It is known that teachers' knowledge about first aid in the school context is very important, emerging the need to have this discipline as a teaching subject in the curriculum. Considering that qualified and confident teachers can teach the basics of first aid to the students and they can act together in the procedures with ability, promoting a broader and adequate care in front of an occurrence of urgency and emergency. [12]

It is necessary that these are consistent with the assumptions of health promotion, however, the implementation of these actions is still a challenge, given the predominance of practices with characteristics still focused on the grievances only when installed [13].

Thus, health promotion consists of actions designed to strengthen the capacity of individuals facilitating favorable means for the health and the community and to carry out strategies of transversal and intersectoral articulation aiming for the quality of life based on the respect for the individual [14].

However, for the execution of these educational activities, the involvement of all stakeholders is an unique condition for the full exercise of health [15], but in the context that surrounds the school environment, one of the challenges for the implementation is the training of education professionals to work with health education. 
The school environment is considered a place where all meet, thus promoting health should be developed not only with teachers, but also in partnership with students, families, staff and health professionals. Building more effective strategies with regards to health and the supply of necessities in the social context [16].

When you perform health promotion activities in the schools, satisfactory changes related to habits, behaviors and attitudes regarding healthy lifestyle are perceived, including physical, mental and social welfare. In addition, health promotion enables the prevention and a better identification of problems and damage to health that can interfere with the learning process of the student [17].

\section{Teacher's performance when facing a school accident}

To act properly when facing school accidents, it is known that basic knowledge about the first aid actions is essential. That way, you can avoid future complications or even save lives.

After addressing the role of teachers facing accidents in the school context, it is clear in the statements below that to stay calm at the time of an occurrence makes all the difference when it is time to perform the first aid to the victim.

[...] stay calm, pass tranquility to them and then seek help, depending if it is an injury, we have the first aid briefcase.

Teacher. 1.

I try to leave the child quiet, immobilized, depending on the incident we send the child to the hospital if necessary.

Teacher. 7.

I maintain myself calm at first, talk to the student sending security to her/him and call for help from colleagues and coordination.

Teacher. 8.
I pull away the other children, take the child to a quiet place and call coordination to decide what to do with the child.

Teacher. 9.

[...] I take him to the coordination so he can receive the first aid.

Teacher. 12.

[...] It is essential to maintain yourself calm and then take the child to the coordination of the school, somewhere where there are the appropriate materials.

Teacher. 13.

Maintaining themselves calm should be the first action of the rescuers when facing an accident; however, each person shows a determined behavior when faced with an urgency and emergency situation. The fear and panic felt when seeing victims in need of help helps a person to experience inappropriate reactions, complicating the correct handling of the victim and thus it may cause some kind of harm to the injured. [18]

In this perspective, remaining calm, rescuers will take the control and leadership of the situation so that in this way they can gain the confidence not only of the victim but also of other people present. To keep calm is the main step to get good results in the course of assistance provided to the victim [19].

The role of the teacher is not based on only the transmission of knowledge but also the promotion of a better quality of life for the student. According to Oliveira [20], so that the quality of life can occur positively, it is necessary that teachers are prepared for any type of event that happens in the school context, but for this, the training of these teachers is essential, transforming trained and qualified teachers to make a difference at the time of an occurrence.

Some teachers still feel afraid to act for not knowing to perform the first aid to the victim; 
many choose individually to seek training courses in first aid. However, this initiative should come from schools, to encourage and promote collective training so that the teachers feel confident in their workplace and even in other environments. [21]

The knowledge and attitudes of teachers about the actions to be taken can negatively influence the school performance and quality of life of a student. Teachers have a key role with substantial influence in the society, however as they do not have technical and scientific knowledge, in most cases, to deal with such situation, they end up bringing risks to the school. [22]

It is noteworthy that prepared and trained teachers ensure a good performance when executing first aid in an accident, which prevents the calling of the rescue team without its necessity. And even with the need to activate the emergency department, they will know how to interact with the team giving all the information needed to obtain success in the recovery of the victim.

\section{"We have the kit, but we do not have the knowledge": elements that facilitate or difficult the performance of teachers}

The urgency and emergency procedures may be performed by anyone who is able to act when there is an accident. This action can be developed individually or collectively and when there is access to materials that are required for the first aid, it will facilitate the proper effectuation of procedures to maintain the vital signs of the victim until the arrival of a team of professionals.

When checking what makes easier for the teachers to act in front of a situation of urgency and emergency, convergences were observed between the various testimonies of the interviewed teachers, as illustrated on below reports:

It makes it easy because we have the support of school management and also have the materials.

Teacher. 4.
Ah, it favors us because we have the first aid kit [...].

Teacher. 7.

What helps me is that here we have medicines at school, in the coordination they have a box with a diversity of remedies in the case of a fall of a child, if they get hurt, we could use oxygenated water and cover that wound [...]

Teacher. 12

$[$...]The materials that we have are what can help Teacher. 13.

However, even with the facilities reported by teachers, difficulties with regards to the lack of knowledge concerning first aid still prevail. Not knowing how to proceed with a victim when an accident occurs generates embarrassment and fear of causing a major problem due to this deficiency, which is exposed in the following reports:

[...] This is exactly what makes it difficult, not knowing how to proceed.

Teacher. 5.

[...] The lack of knowledge is what makes it difficult. Because sometimes we think we're doing the right thing, but we are not.

Teacher. 7.

It is only difficult when I do not know what to do [...]

Teacher. 19.

[...] The absence of knowledge is what makes it difficult, that is, when we do not know what to do.

Teacher. 17.

It is apprehended that although teachers have first aid supplies in their school and at one time or another know how to use them, it is emphasized that the lack of knowledge still prevails as a major difficulty, revealing that having the materials is not enough and it is necessary to know how to use them. 
In this context, it corroborates with Andrade [23] in stating the need to invest in materials to minimize possible suffering of the victims of the accident. It is still important to highlight that the material should be of quality and in sufficient quantity to meet the provision of care appropriately.

To promote an improvement in the practices of first aid performed by these teachers, it is necessary that there is a search for instruments to facilitate the actions when facing situations that require a differentiated service in order to minimize the needs presented by the victims [24].

It is also worth noting that when it comes to medicines, they should only be administered with a doctor's prescription because allergic processes may be triggered if the victim presents a reaction and this can take the victim to death if not rescued immediately [24].

However, knowledge about first aid care is of high importance and favors the correct use of materials. For Vieira [25], knowledge is considered the starting point for decision-making in an attempt to ensure the quality of procedures performed with the victim at the scene, in order to promote and maintain the victim's life.

The lack of knowledge from teachers about the basics of first aid is a disturbing and potentially dangerous trend. This is due to the unpreparedness of educators because they do not have any training promoted by the schools and as a result of this deficiency of knowledge some problems may arise when facing conducts performed improperly. [26]

The continuing education through courses and workshops of improvement comes as a form of teacher's training. This strategy transforms them into active subjects within a care process, since they would go out of their lay position to have a place where they would be helping to reduce risks and save lives. [5]

Health education is an important tool for teacher's training, contributing to the promotion of health. It seeks to strengthen the critical conscience of individuals making them able to perform the designated actions effectively in the search for quality of life; improving and transforming the relationship between living conditions and health [27].

It is noteworthy that to have the strengthening of this critical awareness, health education should be perceived as a teaching/learning process, which can contribute a lot to individuals involved, in this case, teachers, allowing them to view and address the determinants of the health-disease process under a new view of the world [27].

Research should be implemented to give visibility to situations like these, however, while in Brazil the scientific production has been increasing, it would significantly increase with the proper training of health professionals who work with research in project management [28], which would contribute for reorganizing practices and, in turn, the interaction health/school, contributing to the implementation of actions that need to be discussed in this context, such as first aid actions.

On the above, the necessity to explore strategies in schools aimed at promoting specific knowledge for teachers with relation to first aid actions is perceived. Thus, there will be the formation of teachers who are confident in the provision of care avoiding future consequences.

\section{Final Considerations}

It was found that most teachers realize there is a need to obtain knowledge about urgency and emergency situations and the importance to invest in training in schools. The many situations experienced by the teachers who were unable to act when faced with an accident caused many of these to look for first aid courses elsewhere not linked to the school.

The commitment and the fragility of teachers were also found due to the deficiency of health related knowledge, especially with regards to the 
correct procedures to be performed with the victim. To reverse this situation, the implementation of training, lectures, educational programs or even the introduction of first aid discipline in the school context is essential.

Therefore, the need for more studies that address the promotion and protection of health in school environments is highlighted, thus enabling the transformation of teachers in relation to the knowledge of first aid actions. This way, such training will make the teachers skilled to face and know how to act when facing situations that generate a greater complexity in their daily lives.

\section{References}

1. Leite $A C Q B$, Freitas GB, Mesquita MML, França RRF, Fernandes SCA. Primeiros socorros nas escolas. Revista Extendere, 2013; 2(1): 61-70.

2. Fioruc BE, Molina AC, Junior WV, Lima SAM. Educação em saúde: abordando primeiros socorros em escolas públicas no interior de São Paulo. Rev. Eletr. Enf. [Internet]. 2008; 10(3): 695-702. Disponível em: http://www.fen.ufg.br/revista/v10/n3/ v10n3a15.htm. Acesso em 16 de novembro de 2014.

3. Ercan H, Ozen A, Karatepe H, Berber M, Cengizlier R. Primary school teachers' knowledge about and attitudes toward anaphylaxis. Pediatr Allergy Immunol, 2012; 23(5): 428-432

4. Silva HTF, Marques IAC, Barros LCS. A importância da aplicação do treinamento e desenvolvimento nas organizações. Revista Cientifica do ITPAC, 2013; 6(3).

5. Feldens EG, Feldens CA, Kramer PF, Silva KG, Munari CC, Brei VA. Understanding school teacher's knowledge regarding dental trauma: a basis for future interventions. Dental Traumatology, 2010; 26(2): 158-163.

6. Soares MC, Magalhães SCM. Promoção da saúde nas escolas: estudo de contribuição do SAMU com as ações propostas pelas escolas promotoras da saúde. Sinapse Múltipla, 2012; 1(2): 81 93.

7. Turato ER. Tratado da metodologia da pesquisa clínicoqualitativa: construção teórico-epistemológica, discussão comparada e aplicação nas áreas de saúde e humanas. Petrópolis: Ed. Vozes, 2003.

8. Minayo MCS. O desafio do conhecimento. Edição 12. São Paulo: Hucitec, 2010.
9. Bernardes EL, Maciel FA, Del Vecchio FB. Primeiros socorros na escola: nível de conhecimento dos professores da cidade de Monte Mor. Movimento \& Percepção, 2007; 8(11).

10. Sena SP, Ricas J, Viana MRA. A percepção dos acidentes escolares por educadores do ensino fundamental, Belo Horizonte. Rev Med Minas Gerais, 2008; 18(4): 47-54.

11. Tinoco VA, Reis MMT, Freitas LN. O enfermeiro promovendo saúde com educador escolar: atuando em primeiros socorros. Revista Transformar, 2014; (6): 104-113.

12. Stocco JA, Oliveira RC, Romanholo RA, Romanholo HSB. O enfermeiro na educação escolar ensinando noções básicas de primeiros socorros para alunos do ensino fundamental. Revista Eletrônica da Facimed, 2011; 3(3): 363-370.

13. Bezerra IMP, Machado MFAS, Souza OF, Antão JYFLA, Dantas $M N L$, Reis $A O A$, et al. Professional activity in the context of health education: a systematic review. Journal of Human Growth and Development, 2014; 24(3): 255-262.

14. Costa GMC, Cavalcanti VM, Barbosa ML, Celino SDM, França ISX, Sousa FS. Promoção de saúde nas escolas na perspectiva de professores do ensino fundamental. Rev. Eletr. Enf. [Internet]. 2013; 15(2): 506-15. Disponível em: http://dx.doi.org/10.5216/ ree.v15i2.15769. Acesso em 14 de fevereiro de 2015.

15. Atrash HK, Carpentier R. The evolving role of public health in the delivery of health care. Journal of Human Growth and Development, 2012; 22(3): 396-399.

16. Costa FS, Silva JLL, Diniz MIG. A importância da interface educação/saúde no ambiente escolar como prática de promoção da saúde. Informe-se em promoção de saúde, 2008; 4(2): 3033.

17. Lima SC, Magalhães MA, Santos FO. Território escolar, práticas e ações: promoção da saúde na escola. Revista Eletrônica de Geografia, 2012; 4(12): 144-156.

18. Dutra $O O$, Pires $A B$. Noções de primeiros socorros no trânsito. São Paulo: ABRAMET, 2005.

19. Paiano R, Ressurreição KS, Lacerda CS. Conhecimentos sobre primeiros socorros entre profissionais da dança com e sem graduação em educação física. Revista Biomotriz, 2014; 8(1): 01-18.

20. Oliveira IS, Souza IP, Marques SM, Cruz AF. Conhecimento dos educadores sobre a prevenção de acidentes na infância. Rev enferm UFPE, 2014; 8(2): 279-85.

21. Silvani CB, Gomes GC, Souza LD, Souza JL. Prevenção de acidentes em uma instituição de educação infantil: o conhecimento das cuidadoras. Rev. enferm. UERJ, 2008; 16(2): 200-5. 
22. Shehata GA, Mahran DG. Knowledge, attitude and practice with respect to epilepsy among school teachers in Assiut city, Egypt. Epilepsy Research, 2010; 92(2-3): 191-200.

23. Andrade LM, Martins EC, Caetano JA, Soares E, Beserra EP. Atendimento humanizado nos serviços de emergência hospitalar na percepção do acompanhante. Rev. Eletr. Enf. [Internet]. 2009; 11(1): 151-7. Disponível em: http://www.fen.ufg.br/revista/v11/ n1/v11n1a19.htm. Acesso em 16 de novembro de 2014

24. Coelho MF, Chaves LDP, Anselmi ML, Hayashida M, Santos CB. Análise dos aspectos organizacionais de um serviço de urgências clínicas: estudo em um hospital geral do município de Ribeirão Preto, SP, Brasil. Rev. Latino-Am. Enfermagem, 2010; 18(4): 0109.

25. Vieira LJES, Carneiro RCMM, Frota MA, Gomes ALA, Ximenes LB. Ações e possibilidades de prevenção de acidentes com crianças em creches de Fortaleza, Ceará. Ciência \& Saúde Coletiva, 2009; 14(5): 1687-1697.

26. Bishop M, Boag EM. Teachers' knowledge about epilepsy and attitudes toward students with epilepsy: results of a national survey. Epilepsy Behav. 2006; 8(2): 397-405.

27. Bezerra HMC, Machado MFAS, Antão JYFLA, Monteiro CBM, Abreu LC, Garcia TTB, et al. Community health agents and the interface with educational actions. International Archives of Medicine, 2015; 8(153): 01-10.

28. Monteiro CBM, Almeida Junior AD, Wajnzstejn R. Project Management in Health and Medical Research. Journal of Human Growth and Development. 2014; 24(3): 239-242.

\section{Comment on this article:}

\section{(f) [in is $\mathbf{S}$ ?}

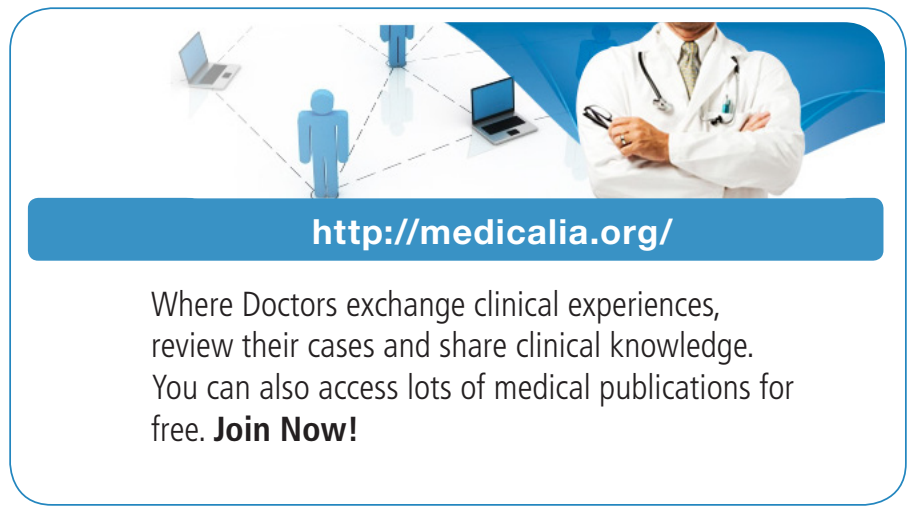

\section{Publish with iMedPub}

http://www.imed.pub

International Archives of Medicine is an open access journal publishing articles encompassing all aspects of medical science and clinical practice. IAM is considered a megajournal with independent sections on all areas of medicine. IAM is a really international journal with authors and board members from all around the world. The journal is widely indexed and classified Q1 in category Medicine. 